\title{
Regulation of hepatic nitrogen metabolism in ruminants
}

\author{
BY G. E. LOBLEY AND G. D. MLANO* \\ Rowett Research Institute, Bucksburn, Aberdeen AB21 9SB
}

As befits its anatomical position between the sites of nutrient absorption and deposition the liver provides the metabolic hub of the body. Although the present review is confined to the regulation of $\mathrm{N}$ substrates it must not be forgotten that both lipid and carbohydrate metabolism are important and interactive components of hepatic function. Furthermore, hepatic production of insulin-like-growth-factor (IGF)-1 and partial removal of glucagon and insulin play an important part in regulation of peripheral endocrine balance. These hormonal events are linked to peripheral appearance of two of the major $\mathrm{N}$ products of digestion and absorption, $\mathrm{NH}_{3}$ and amino acids (AA), which are both under the control of hepatic metabolism. Thus, in order to provide the required homeostatic and homeorhetic control, complex mechanisms must operate in vivo but, to date, much of our understanding of these involves use of isolated primary hepatocytes and perfused livers derived from nonruminant sources. The commercial species, pigs, cattle and sheep, offer the unique opportunity to establish chronic arterio-venous preparations across the splanchnic tissues and these have provided the basis for the majority of longitudinal studies in vivo. Nonetheless, the data mass is still small and it is currently necessary to assume that acute findings, both in vivo and in vitro, from laboratory animals can be extrapolated to ruminants.

Despite an outward homogeneous appearance the structure of the liver is both complex and ordered. For example, hepatocytes have a polar nature between their sinusoidal and canicular surfaces and this important feature of metabolic regulation is lost when isolated hepatocytes are prepared. Furthermore, there is localization of different subpopulations of hepatocytes, with the dominant $(>0.9$ in the rat) periportal species being specialized for ureagenesis, gluconeogenesis, glutaminolysis and synthesis of plasma albumin (Häussinger et al. 1992a), as well as exhibiting greater activity of the enzymes of AA catabolism (see Häussinger, 1990). In contrast, the minority perivenous cells, which are restricted to a few cell layers around the efferent hepatic vein, can synthesize glutamine and extract aspartate and glutamate from blood (Stoll et al. 1991).

This spatial organization provides a hierarchy for the fates of metabolites and is an important feature for the roles that the liver has to accomplish. The present short review will focus on two of those roles, detoxification of $\mathrm{NH}_{3}$ and the hepatic partition of absorbed AA between catabolism and protein anabolic fates within the liver, as well as the ensuing consequences for the availability of AA sources to the peripheral tissues.

\section{UREAGENESIS}

\section{Ammonia detoxification}

One vital hepatic function in all mammals is detoxification of $\mathrm{NH}_{3}$, produced from bacterial fermentation or metabolism within the gastrointestinal tract (GIT) and peripheral tissues. Extraction of $\mathrm{NH}_{3}$ by the liver is very efficient with, in sub-overload situations, apparent fractional extractions of $0.75-0.85$ (for example, see Reynolds et al. 1991).

* Present address: Departamento de Fisiopatología, Facultad de Ciencias Veterinarias, UNCPBA, Campus Universitario (7000) Tandil, Argentina. 
Indeed, recent data, based on isotope extractions, indicate that removal from non-hepatic sources may be as great as $98 \%$ (Nieto et al. 1996), but this is partly offset by $\mathrm{NH}_{3}$ production from hepatic or vascular sources during transit of blood across the liver. Incomplete extraction, due either to liver damage or excessive $\mathrm{NH}_{3}$ absorption, results in peripheral hyperammonaemia which can cause inappetance, infertility, coma and death. The main fates of the removed $\mathrm{NH}_{3}$ are, in sheep, directed towards synthesis of urea and, to a lesser extent, glutamine (Lobley et al. 1995, 1996).

One question that has been addressed recently is whether the removal of $\mathrm{NH}_{3}$ incurs a penalty on AA catabolism (Reynolds, 1992). The original concept arose from several observations in cattle where hepatic removal of $\mathrm{NH}_{3}-\mathrm{N}$ only accounted for $0.5-0.6$ of urea$\mathrm{N}$ output (see Lobley et al. 1995). It has long been established that each of the $\mathrm{N}$ atoms of urea are supplied from balanced inputs of mitochondrial $\mathrm{NH}_{3}$ and cytosolic aspartate respectively. In non-ruminants, the latter is usually produced by transamination reactions linked to glutamate, with $\mathrm{NH}_{2}$ groups from other AA as possible donor sources. Thus, it appeared plausible that, for ruminants under conditions when $\mathrm{NH}_{3}$ supply was in excess, AA- $\mathrm{N}$ would be transferred to aspartate to allow ureagenesis to proceed at rates which prevent peripheral hyperammonaemia. Animals with poor capture of $\mathrm{NH}_{3}$ within the rumen would have, therefore, the double penalty of first, less dietary $\mathrm{N}$ converted to microbial protein and second, utilization of some of the absorbed AA to support hepatic ureagenesis to remove the excess $\mathrm{NH}_{3}$.

Within liver mitochondria, however, two specialized mechanisms have evolved to maintain equal $\mathrm{N}$ inflows to carbamoyl phosphate and aspartate when substrate supplies are imbalanced. The first involves glutaminase ( $E C$ 3.5.1.2) which releases $\mathrm{NH}_{3}$ from glutamine to provide additional substrate for carbamoyl phosphate synthetase ( $E C$ 6.3.4.16; CPS1). This is important when excess AA are absorbed and the surplus $\mathrm{NH}_{2}-\mathrm{N}$ is transferred via glutamate to aspartate; this situation often occurs with non-ruminants maintained on high-protein diets. There is some evidence that $\mathrm{NH}_{3}$ liberated from glutamine is preferentially channelled to carbamoyl phosphate synthesis due to the close physical proximity of glutaminase and CPS1 on the inner membrane of the mitochondrion (Meijer et al. 1985). The second mechanism, which permits $\mathrm{NH}_{3}-\mathrm{N}$ to enter the ornithine cycle via both carbamoyl phosphate and aspartate, involves glutamate dehydrogenase $(E C$ 1.4.1.2; GDH). Under normal mitochondrial $\mathrm{NADH}: \mathrm{NAD}^{+}$conditions this enzyme strongly favours synthesis of glutamate from $\mathrm{NH}_{3}$ and 2-oxoglutarate and is coupled with aspartate : 2-oxoglutarate transaminase ( $E C$ 2.6.1.1; AOT) to yield aspartate, which is then transported from the mitochondrion and provides substrate for cytosolic argininosuccinate synthetase ( $E C$ 6.3.4.5; ASS), situated in close proximity to the outer mitochondrial membrane (Cohen \& Kuda, 1996).

For the ruminant, the question is how active is the GDH-AOT axis relative to maximal rates of ureagenesis, i.e. can sufficient aspartate and carbamoyl phosphate be derived from $\mathrm{NH}_{3}-\mathrm{N}$ without the need to invoke additional AA catabolism? Initial studies based on infusion of $\mathrm{NH}_{4} \mathrm{Cl}$ into the mesenteric vein for either acute $(3 \mathrm{~h}$; Wilton et al. 1988) or chronic (4 d; Lobley et al. 1995) periods yielded increases in hepatic urea-N output twofold greater than the additional $\mathrm{NH}_{3}-\mathrm{N}$ administered, with an accompanying increase in leucine oxidation across the splanchnic bed (Lobley et al. 1995). This implied that the GDH-AOT activity might limit the transfer of $\mathrm{NH}_{3}$ to aspartate, but the data were compromised by the associated mild metabolic acidosis which can result in enhanced amino acid catabolism and stimulation of ureagenesis (Reaich et al. 1992). When the experiments were extended, but with use of $\mathrm{NH}_{4} \mathrm{HCO}_{3}$ whereby arterial $\mathrm{pH}$ remained unchanged, the additional urea- $\mathrm{N}$ produced was equivalent to only 1.2 of the extra $\mathrm{NH}_{3}-\mathrm{N}$ infused and with no alteration in 
Table 1. Hepatic $N$ exchanges ( $\mu \mathrm{mol} / \mathrm{min}$ ) in response to 4 d intra-mesenteric vein infusions of ammonium bicarbonate in sheep

\begin{tabular}{|c|c|c|c|c|}
\hline $\mathrm{NH}_{4} \mathrm{HCO}_{3}$ infusion $(\mu \mathrm{mol} / \mathrm{min})$. & 0 & 150 & 400 & $\begin{array}{l}\text { Statistical significance } \\
\text { of difference: } P\end{array}$ \\
\hline \multicolumn{5}{|l|}{ Removals } \\
\hline $\mathrm{NH}_{3}$ & -391 & -600 & -954 & $<0.001$ \\
\hline AA-N (plasma) & -260 & -312 & -323 & NS \\
\hline \multicolumn{5}{|l|}{ Output } \\
\hline Urea-N & 710 & 912 & 1356 & 0.002 \\
\hline $\mathrm{NH}_{3}-\mathrm{N}$ : urea-N & \multirow{2}{*}{\multicolumn{2}{|c|}{1.03}} & \multirow[b]{2}{*}{0.80} & 0.065 \\
\hline Incremental $\mathrm{NH}_{3}-\mathrm{N}$ : urea- $\mathrm{N}$ & & & & \\
\hline
\end{tabular}

AA, amino acid.

leucine oxidation (Lobley et al. 1996), in agreement with recent observations in ovine hepatocytes where oxidation of both alanine and glutamate were unaffected by $\mathrm{NH}_{3}$ load (Mutsvangwa et al. 1996).

In addition, when ovine primary hepatocytes were incubated in the presence of ${ }^{15} \mathrm{NH}_{3}$, $\left[{ }^{15} \mathrm{~N}^{15} \mathrm{~N}\right]$ urea was the predominant product, when AA were absent from the medium, while both $\left[{ }^{15} \mathrm{~N}^{15} \mathrm{~N}\right]$ - and $\left[{ }^{14} \mathrm{~N}^{15} \mathrm{~N}\right]$ urea were synthesized when AA were present, clearly demonstrating that $\mathrm{N}$ for both aspartate and carbamoyl phosphate arose from $\mathrm{NH}_{3}$ (Luo $e t$ al. 1995). Of particular interest was that the maximal rates of ureagenesis in vitro were similar either with $\mathrm{NH}_{3}$ alone or with the physiological mixture of AA present. Thus, ureagenesis was not constrained in vitro by the ability of GDH and AOT to transfer the $\mathrm{N}$ of $\mathrm{NH}_{3}$ to aspartate. It would be unwise to extrapolate these data in vitro directly to the whole liver because the maximal rates of ureagenesis were only approximately 0.5 those observed in vivo. When, however, $\mathrm{NH}_{3}$ supply to the ovine liver was artificially augmented over a $4 \mathrm{~d}$ period, by intra-mesenteric vein infusion of various quantities of $\mathrm{NH}_{4} \mathrm{HCO}_{3}$ such that $\mathrm{NH}_{3}-\mathrm{N}$ : AA-N extracted by the liver was increased from 1.5 to 2.9 (to cover the range of inputs observed in the various nutritional studies), then approximately 0.9 of the additional urea- $\mathrm{N}$ produced could be attributed to $\mathrm{NH}_{3}$ with only small, non-significant increases in the amount of hepatic AA-N extracted (Table 1).

These recent data, both in vitro and in vivo, suggest, therefore, that the efficiency with which the ruminant liver is able to remove $\mathrm{NH}_{3}$ does not incur a severe penalty on AA catabolism, although in the context of an animal which may already be protein restricted (in terms of supply to peripheral tissues) even a requirement of $10 \%$ towards additional ureagenesis may limit productive output and commercial advantage.

\section{NON-AMMONIA INPUTS}

Several studies have shown that, in ruminants, there is a finite capacity of hepatic ureagenesis with respect to acute removal of $\mathrm{NH}_{3}$ (approximately $1.5-2.0 \mu \mathrm{mol}$ urea- $\mathrm{N} / \mathrm{g}$ liver per min; for example, see Symonds et al. 1981; Orzechowski et al. 1987; see Table 1). Absorption of either $\mathrm{NH}_{3}$ or AA in excess of ureagenic capacity, as may occur in the short term during the postprandial state, thus sets a question of priority to the liver: does prevention of peripheral hyperammonia become more important than maintenance of euaminoacidaemia? If so, can excess $\mathrm{NH}_{3}$ provision actually prevent acute oxidation of $\mathrm{AA}$ due to selective inflow into the ornithine cycle? 
Infusion of $\mathrm{NH}_{4} \mathrm{HCO}_{3}$ at $1.1 \mathrm{mmol} / \mathrm{min}$ for $20 \mathrm{~min}$, into sheep fed to $1.5 \times$ maintenance, created a situation whereby ureagenesis became maximal at $1.4 \mathrm{mmol}$ urea- $\mathrm{N} / \mathrm{min}$ (i.e. peripheral hyperammonaemia occurred) and the contribution of hepatic $\mathrm{NH}_{3}-\mathrm{N}$ removal to urea-N synthesis increased from 0.46 under basal conditions to 0.89 (Fig. 1). The apparent inputs required from other $\mathrm{N}$ sources (presumably $\mathrm{AA}$ ) into the ornithine cycle were reduced. There was, however, no significant decrease in AA uptake by the liver which meant that alternative fates, other than ureagenesis, for either $\mathrm{NH}_{3}$ or $\mathrm{AA}$ must have occurred. The most probable routes include, for $\mathrm{NH}_{3}$, synthesis of glutamine in the perivenous cells and, for AA, either expansion of the liver intracellular free pools or production of constitutive and/or export protein.

What then occurs for the alternative scenario when AA supply is enhanced; does this result in lowered apparent $\mathrm{NH}_{3}$ removal? The answer appears to be a categorical 'no'. With sheep fed to $1.5 \times$ maintenance, acute $(4 \mathrm{~h})$ infusion into the mesenteric vein of graded amounts (to $2 \mathrm{mmol} \mathrm{N} / \mathrm{min}$ ) of an $\mathrm{AA}$ mixture, based on the composition of rumen microbial protein, again resulted in a maximal rate of hepatic ureagenesis, similar to that observed with short-term $\mathrm{NH}_{4} \mathrm{HCO}_{3}$ administration, but the absolute hepatic extraction of $\mathrm{NH}_{3}$ remained constant, although the fractional contribution to ureagenesis decreased (Fig. 2 ). The similarity in maximum velocity $\left(V_{\max }\right)$ under conditions of excess $\mathrm{NH}_{3}$ and $\mathrm{AA}$ supply would suggest that the rate-limiting step is at either the CPS1 or AOT-ASS pathways, with the former more probable, based on data from non-ruminants (Meijer et al. 1990; see p. 552). At all infusion levels only $30 \%$ of the exogenous AA-N was removed

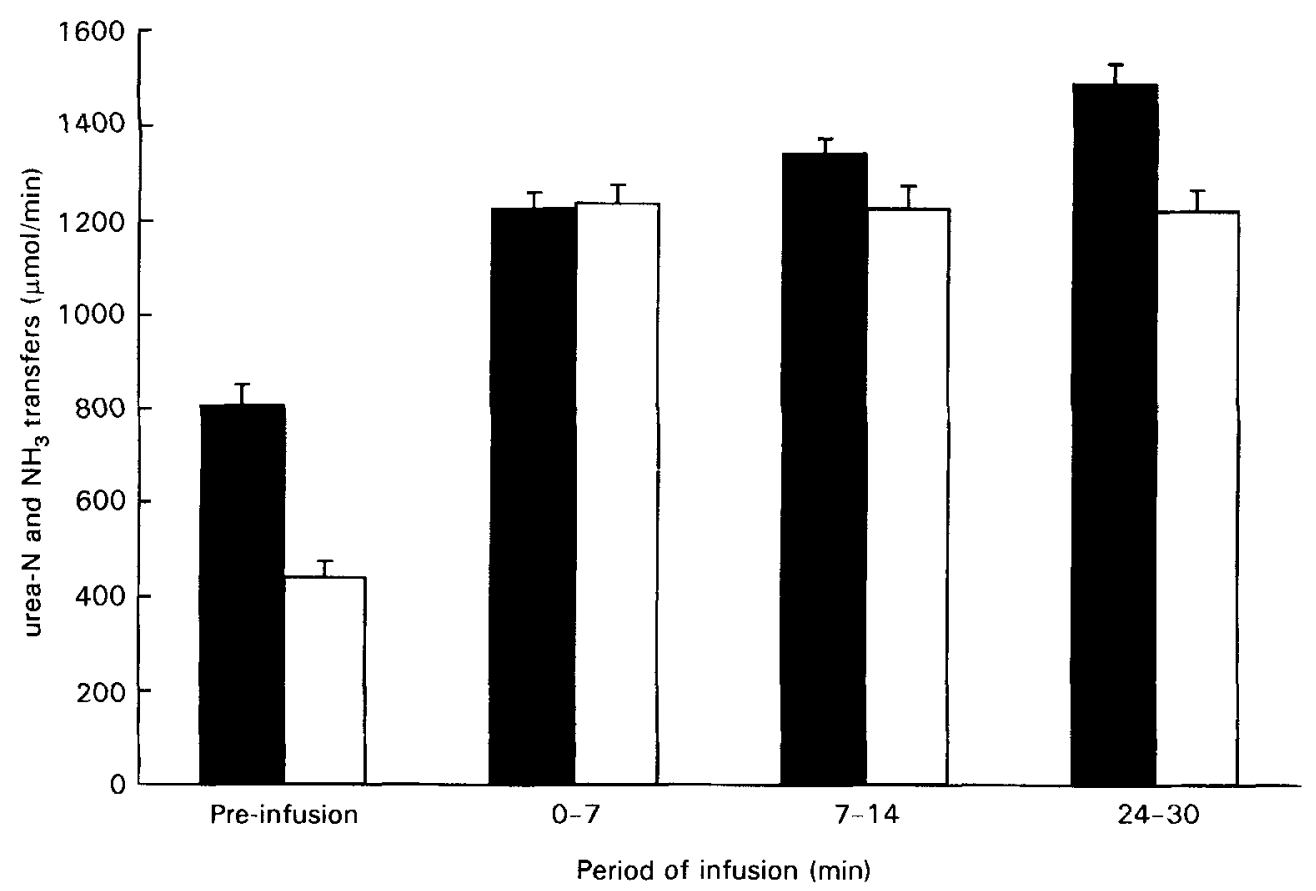

Fig. 1. Release of urea-N ( $\square$ ) and uptake of ammonia $(\square)$ by the liver of $45 \mathrm{~kg}$ sheep maintained at $1.2 \times$ maintenance on grass pellets and infused for $21 \mathrm{~min}$ with $1.1 \mathrm{mmol}$ ammonium bicarbonate/min into the mesenteric vein. The basal plus exogenous $N$ inputs exceed the capacity of the liver to synthesize urea- $N$ (about $2 \mu \mathrm{mol} / \mathrm{g}$ liver per min). Values are means with their standard errors represented by vertical bars. 


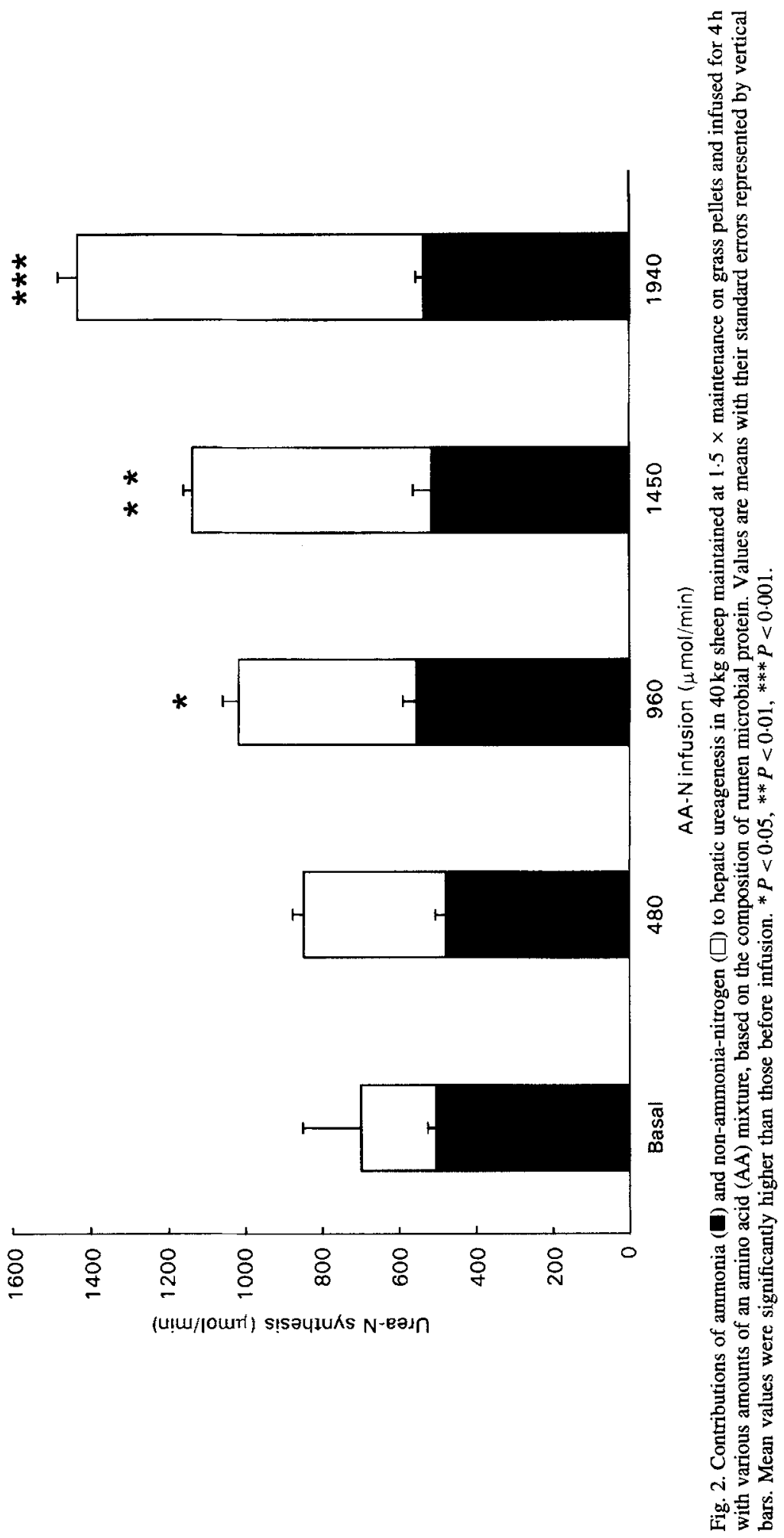


across the liver and, thus, peripheral hyperaminoacidaemia appeared to be a preferred option to hyperammonaemia.

\section{REGULATION}

Although removal of $\mathrm{NH}_{3}$ can be perceived as an important and beneficial role of ureagenesis, the catabolism of AA (particularly when these are not in excess from the diet) represents a disadvantage, either potential or real, for animal production. Ultimately, all absorbed AA which are not used for protein anabolism enter catabolic pathways with urea as the major endproduct; but to what extent is hepatic removal of AA a regulated process? Does the first pass phenomenon lead to an inevitable (and obligatory) catabolism of absorbed AA, or is control strictly exerted such that ureagenesis is determined by peripheral tissue needs, presumably under hormonal (or neuroendocrine) control? The latter situation must occur, to some extent at least, in that animals maintained on controlled intakes, with presumably constant amounts of AA absorbed, can alter protein retention in response to exogenous agents, such as growth hormone and certain $\beta$-agonists, and, thus, urea synthesis must be depressed. It is still unclear, however, the extent to which these changes result from direct regulation of ureagenesis or are simply a response to lowered AA supply recycled from peripheral tissues.

In terms of direct regulation, it is usually considered that the rate-limiting step in ureagenesis involves synthesis of mitochondrial carbamoyl phosphate (by CPS1), which has a putative control coefficient of 1 (Meijer et al. 1990), although based on $V_{\max }$ values an argument could also be advanced for cytosolic ASS (Owczarczyk \& Barej, 1975). What makes CPS1 such an attractive candidate is that it is regulated by the activator $\mathrm{N}$ acetylglutamate (N-AG), which is synthesized within mitochondria through N-AG synthetase, the activity of which is controlled by phosphorylation status, a mechanism which contributes both rapidity and sensitivity. Among the known regulators of N-AG synthietase are included glucagon, glucocorticoids and certain metabolites (Hensgens et al. 1980).

Studies with rodent hepatocytes have also indicated that propionate also inhibits ureagenesis through reduction of $\mathrm{N}-\mathrm{AG}$ synthesis (Stewart \& Walser, 1980) and this provides an attractive hypothesis to explain the enhanced protein anabolism that often occurs with concentrate as opposed to roughage diets (for example, see Reynolds et al. 1991). Compared with non-ruminants, liver mitochondria from ruminants are also more sensitive to propionate (inhibitor constant, $K_{i}$, of $0.86 v .1 .7 \mathrm{mM}$; Rattenbury et al. 1983; Orzechowski \& Motyl, 1989) which, at a concentration of $0.5 \mathrm{mM}$, decreased citrulline production by $80 \%$ (Rattenbury et al. 1983). Similarly, in the perfused ovine liver $0.5 \mathrm{mM}$ propionate lowered ureagenesis by $20-30 \%$ (Richardson et al. 1982). In contrast, other researchers have observed, for ovine hepatocytes incubated with propionate, either no effect (Demigné et al. 1991) or an increase (Garwacki et al. 1990; Demigné et al. 1991) in urea production. The pre-incubation conditions for some of these studies in vitro have involved basal media, deficient in many metabolites, but with supraphysiological amounts of propionate, $\mathrm{AA}$ or $\mathrm{NH}_{3}$ then added. Minimum quantities of a $\mathrm{C}_{3}$ source (propionate, lactate, alanine etc.) are needed to allow ureagenesis to proceed and, if this requirement is neglected, addition of propionate to a deficient basal medium may result in concomitant stimulation and inhibition. This was clearly demonstrated when graded quantities of propionate, encompassing the physiological range, were added to ovine hepatocytes incubated in the presence of physiological concentrations of $\mathrm{NH}_{3}$ and/or AA (Table 2). With low propionate there was an initial stimulation of ureagenesis; inhibition only 
Table 2. Effect of propionate concentration on ammonia uptake and urea production by ovine hepatocytes (M. A. Lomax, G. E. Lobley and G. D. Milano, unpublished results)

\begin{tabular}{cccc}
\hline \hline & \multicolumn{2}{c}{ Transfers (nmol/h per mg wet cells) } \\
\cline { 2 - 4 } Propionate (mM) & $\mathrm{NH}_{3}$ uptake & urea-N release & $\mathrm{NH}_{3}:$ urea-N \\
\hline 0 & $-17.0^{\mathrm{a}}$ & $28.9^{\mathrm{a}}$ & 0.61 \\
0.2 & $-57.6^{\mathrm{b}}$ & $62.8^{\mathrm{b}}$ & 0.92 \\
0.4 & $-54.3^{\mathrm{b}}$ & $63.6^{\mathrm{b}}$ & 0.87 \\
0.8 & $-42.5^{\mathrm{c}}$ & $56 \cdot 0^{\mathrm{b}, \mathrm{c}}$ & 0.79 \\
1.6 & $-35.6^{\mathrm{c}}$ & $42 \cdot 0^{\mathrm{c}}$ & 0.86 \\
$\mathrm{SED}$ & 4.56 & 5.98 & 0.061 \\
\hline \hline
\end{tabular}

${ }^{a, b, c}$ Values within columns with different superscripts were significantly different $(P<0.01)$.

occurred above $0.4 \mathrm{mM}$, greater than the concentrations normally observed in vivo. Direct measurement of hepatic urea synthesis in vivo in response to acute treatment with propionate failed to elicit any response, although these data are unusual in that increases in ureagenesis were delayed for several hours following $\mathrm{NH}_{3}$ infusion (Orzechowski et al. 1988). Furthermore, their use of a mixed concentrate ration may have already established maximal inhibition conditions in vivo.

It is often considered that propionate may provide greater quantities of gluconeogenic substrate and reduce the demands on AA to provide $\mathrm{C}$ for glucose synthesis. In practice, the major gluconeogenic AA substrates are the non-essential AA, alanine, glutamine (converted to glutamate) and glycine and/or serine (Wolff \& Bergman, 1972), and, thus, the rationale for a profound effect on protein anabolism by removal of essential AA, especially those which are often limiting (e.g. methionine, lysine etc.) is not easy to sustain. Where propionate does effect ureagenesis this may be through either preferential esterification with $\mathrm{CoA}$, reducing the amount of acetyl-CoA available to $\mathrm{N}-\mathrm{AG}$ synthetase, or by depletion of mitochondrial ATP, which would restrict N-AG formation and CPS1 activity (Orzechowski \& Motyl, 1989). In contrast, the stimulatory effect of glucagon on urea synthesis involves increased ATP provision and intra-mitochondrial concentration of N-AG (Hensgens et al. 1980; Verhoeven et al. 1982).

Ureagenesis represents the non-productive aspect of hepatic $\mathrm{N}$ metabolism, although opportunities to improve animal productivity may involve inhibition of inflows into the ornithine cycle, either in a general manner, i.e. suppression of total entry of AA or, more specifically, through inhibition of the catabolism of specific, limiting AA.

\section{HEPATIC PROTEIN TURNOVER}

The anabolic fate of AA extracted by the liver can be divided into two categories, net production of constitutive protein and the synthesis, followed by release, of export components, usually plasma protein. Both protein pools can expand or contract $( \pm 100 \mathrm{~g}$ in a $40 \mathrm{~kg}$ sheep) in response to altered nutrition (for example, see Burrin et al. 1990; Connell et al. 1997).

\section{EXPORT PROTEINS}

Albumin represents $35 \%$ of ovine plasma protein but $60 \%$ of total albumin is distributed in the extravascular space (Abbott et al. 1985). Hepatic synthesis of albumin can vary by 
Table 3. Hepatic constitutive and export protein synthesis in fed and $3 d$ fasted sheep (Data from Connell et al. 1997)

\begin{tabular}{|c|c|c|}
\hline & Fasted & Fed \\
\hline \multicolumn{3}{|l|}{ Protein synthesis $(\mathrm{g} / \mathrm{d})$} \\
\hline Constitutive & 26 & 26 \\
\hline Albumin & 2.4 & $4 \cdot 2^{* *}$ \\
\hline Non-albumin $\dagger$ export protein & $11 \cdot 0$ & $12 \cdot 4$ \\
\hline \multicolumn{3}{|l|}{ Plasma protein } \\
\hline \multicolumn{3}{|l|}{ Mass $(\mathrm{g})$} \\
\hline Total & 145 & $151^{*}$ \\
\hline Albumin§ & 52 & $67^{* *}$ \\
\hline \multicolumn{3}{|l|}{ Rate of change $(\mathrm{g} / \mathrm{d})$} \\
\hline Total & \multicolumn{2}{|c|}{2} \\
\hline Albumin§ & \multicolumn{2}{|c|}{12} \\
\hline
\end{tabular}

Values were significantly different from those for fasted sheep: $* P<0 \cdot 05, * * P<0.01$.

$\dagger$ Assumes that all non-albumin plasma protein synthesis is of hepatic origin.

$\ddagger$ Assumes plasma volume is unaltered between fed and fasted state.

$\S$ Assumes albumin is distributed $0.4: 0.6$ between vascular and extravascular compartments.

20-75\% in both sheep and man in response to chronic or acute changes in intake (Hunter $e t$ al. 1995; Connell et al. 1997), with smaller increases for the other export proteins (Table 3). Such changes are sufficient to accommodate most of the accompanying alterations in plasma protein content but, for albumin, apparently extrahepatic degradation must also change (Table 3).

Albumin only contributes $15-22 \%$ to export protein production, which represents 30 $35 \%$ of total hepatic protein synthesis (Table 3 ). The contribution of albumin to the total is, however, greater in the fed than in the fasted state $(10 \mathrm{v.} 6 \%$ respectively; Connell et al. 1997). Based on these data, the hepatic fates of extracted AA between export protein synthesis and, by difference, oxidation can be calculated. For the essential AA the proportion directed to net protein gain varies between 0.10 and 0.73 , with methionine and lysine representing the extremes (Table 4). The majority of values for oxidation are calculated indirectly but the direct data available for leucine catabolism provide excellent agreement with this procedure (Table 4 ).

Table 4. Net fate of essential amino acids during transit across the liver of sheep fed to $1.5 \times$ maintenance (Data from Connell et al. 1997 and G. E. Lobley, unpublished results)

\begin{tabular}{lcccrrr}
\hline \hline Fates (mmol/min) & His & Lys & Phe & Met & Thr & Leu \\
\hline Hepatic extraction & -9.1 & -17.7 & -23.2 & -7.3 & -13.7 & -13.3 \\
Albumin synthesis & 0.7 & 2.7 & 1.1 & 0.2 & 1.6 & 2.4 \\
Globulin synthesis* & 4.3 & 10.2 & 4.1 & 0.6 & 3.6 & 4.7 \\
Oxidation $\dagger$ & $(4.1)$ & $(4.8)$ & $(18.0)$ & $(6.5)$ & $(8.5)$ & 5.8 \\
\hline \hline
\end{tabular}

* Assumes $80 \%$ of non-albumin synthesis of plasma protein are globulins of hepatic origin.

$\dagger$ As the difference between extraction and export protein synthesis except for leucine which is interpolated from Lobley et al. $(1995,1996)$. 


\section{REGULATION OF HEPATIC PROTEIN TURNOVER}

\section{Proteolysis}

The limited evidence available for sheep suggests that constitutive synthesis of hepatic protein is not particularly responsive to nutritional status (Attaix et al. 1987; Lobley et al. 1994; Connell et al. 1997) and, thus, the large changes in liver mass which occur with intake (Burrin et al. 1990) must be due to changes in proteolysis. Indeed, it has been known for many years that, in rodents, specific AA have reproducible anti-proteolytic effects in the liver (Mortimore \& Pösö, 1987). Such observations have not been extended to ruminants but, based on the assumption that common mechanisms exist for all mammals, recent data suggest that some of the anti-proteolytic effects of both nutrients and hormones may be exerted through changes in cellular volume (see Häussinger et al. 1994). Factors which result in the swelling of either isolated hepatocytes or the perfused liver cause, within a few minutes, responses in carbohydrate, AA and protein metabolism, with a decrease in proteolysis the most consistent event (Häussinger et al. 1991). Indeed, for hepatocytes or perfused livers bathed with certain AA and hormones there is an approximately linear relationship between cell volume and rate of proteolysis (for example, see Häussinger et al. 1994).

The mechanisms underlying the changes in proteolysis are uncertain, but the effects are lost if perturbation or destruction of the intracellular microtubular system occurs (vom Dahl et al. 1995). The microtubular system provides the membrane for the early stage of autophagic vacuole formation which involves a non-selective sequestration of cytosolic contents, and these will be more 'dilute' in terms of protein concentration if cell volume has increased due to hydration events. Cell swelling also causes alkalinization, by inhibition of the proton pump of the vacuole membrane, as the autophagosomes mature to lysosomes and, thus, the acid conditions necessary for full lysosomal action are not achieved (Luiken et al. 1996).

Both AA and hormones can alter cell hydration through alteration of the intracellular $\mathrm{K}^{+}$concentration. Those AA which are transported by $\mathrm{Na}^{+}$-dependent mechanisms (and can accumulate by $10-20$-fold against the concentration gradient) are particularly effective; these include glycine, alanine and glutamine (for example, see vom Dahl \& Häussinger, 1996), all of which can be maintained at millimolar quantities within ruminant hepatocytes both in vitro and in vivo (Demigné et al. 1991; Lobley et al. 1996). Thus, this provides a mechanism whereby cellular metabolism can be linked rapidly to nutritional status. Further nutritional sensitivity is achieved because the hydration response to glycine is approximately 3 -fold greater (more sensitive) with hepatocytes isolated from fasted rodents compared with fed rodents (vom Dahl \& Häussinger, 1996).

Insulin also increases the hydration status of hepatocytes (through $\mathrm{Na}^{+}-\mathrm{H}^{+}$exchange, co-transport of $\mathrm{Na}^{+} / \mathrm{K}^{+} 2 \mathrm{Cl}^{-}$and $\mathrm{Na}^{+} / \mathrm{K}^{+}$-ATPase (EC 3.6.1.36) activity) but, in contrast to glycine, the sensitivity is superior with cells isolated from fed animals (vom Dahl \& Häussinger, 1996), which fits with the known refractory response of the fasted liver to the hormone (Karasik et al. 1990). Not surprisingly glucagon has opposing effects because, although similar ion transport exchanges occur as with insulin, it produces additional opening of $\mathrm{K}^{+}$channels leading to cell loss of $\mathrm{K}^{+}$, and thus cell shrinkage (see Häussinger et al. 1994). Again, as observed with the AA, the effects of both hormones on systems in vitro occur at physiological concentrations, e.g. for the rat half-maximal activity on cell hydration is observed at hormone levels present in hepatic portal blood (vom Dahl et al. 1991). Increased IGF-1 also has a positive effect on hepatocyte hydration (vom Dahl \& Häussinger, 1996). 
Cellular hydration should not be seen as an open-ended process, however, in that counter-regulatory mechanisms operate to limit cell volume changes to approximately 10$25 \%$ within perfused liver and hepatocytes (vom Dahl \& Häussinger, 1996).

\section{PROTEIN SYNTHESIS}

Effects of increased hepatocyte water on protein synthesis are more equivocal, with reports of either an increase or no change, although the latter observations occurred with cells already acclimated to twice normal AA concentrations (Stoll et al. 1992). Certainly events which result in hepatocyte shrinkage led to concomitant decreases in protein synthesis and increases in protein breakdown (Stoll et al. 1992).

Although the limited data available for the ruminant in vivo would suggest the effect on constitutive protein synthesis to be minimal, hydration does stimulate the protein kinases Erk-1 and Erk-2 leading to increases in both phosphorylation of c-Jun and c-Jun mRNA abundance (Schliess et al. 1995). Other mitogen-activated kinase-regulated phosphorylations also occur, including those involving ribosomal protein S6 (Luiken et al. 1994). These phosphorylation events may be important in resolving one conundrum from the observations in vivo; notably, how is differential regulation of constitutive (via proteolysis) and export (via synthesis) protein metabolism modulated? One possibility (see Fig. 3 ) is that the phosphorylation events aid the localization of mRNA for export proteins towards the rough endoplasmic reticulum (mediated in part by the $3^{\prime}$-untranslated region; Hesketh, 1994). This directs both the mRNA and synthesized preproteins away from the cytosol, where the first non-specific vacuole formation occurs as a precursor to intracellular degradation. Furthermore, increased binding of ribosomes (possibly as a consequence of S-6 phosphorylation; Luiken et al. 1994) to the microtubular system to form rough endoplasmic reticulum will stabilize the membrane integrity and inhibit autophagic vacuole formation while at the same time providing a spatial organization directed towards export protein synthesis (Luiken et al. 1994).

\section{OTHER REGULATIONS}

Increased cell hydration also stimulates AA catabolism and ureagenesis, the latter possibly by increases in ASS activity (Quillard et al. 1996), although reduced ATP concentrations may also be important (Cathelineau et al. 1979). Glycine oxidation (Häussinger et al. $1992 b$ ) and glutaminase activity (Häussinger et al. 1990) are both enhanced by mitochondrial swelling and may be seen as mechanisms by which the cell stabilizes hydration state and resets the system. The return to an iso-osmotic state is also aided by reduced glutamine synthesis within the perivenous hepatocytes (Häussinger et al. 1990). The elevated glutaminolysis may also account for the reduced synthesis of urea from $\mathrm{NH}_{3}$ observed in swollen hepatocytes from rats, i.e. glutamine amido- $\mathrm{N}$ may provide a preferential substrate for CPS 1 .

Although this concept of regulation of cellular metabolism through hydration is attractive, and provides for a variety of substrates and hormones a common mechanism, it is not exclusive. Only part of the effect of proline, for example, can be ascribed to changes in cell volume (Häussinger et al. 1994). Furthermore, one of the most powerful regulators of proteolysis is leucine, which has $\mathrm{Na}^{+}$-independent transport and does not stimulate cell swelling. Instead, leucine probably inhibits directly the lysosomal proton pump and the ensuing alkalinization of the vacuole contents reduces peptide bond cleavage (Luiken $e t$ al. 1996). 

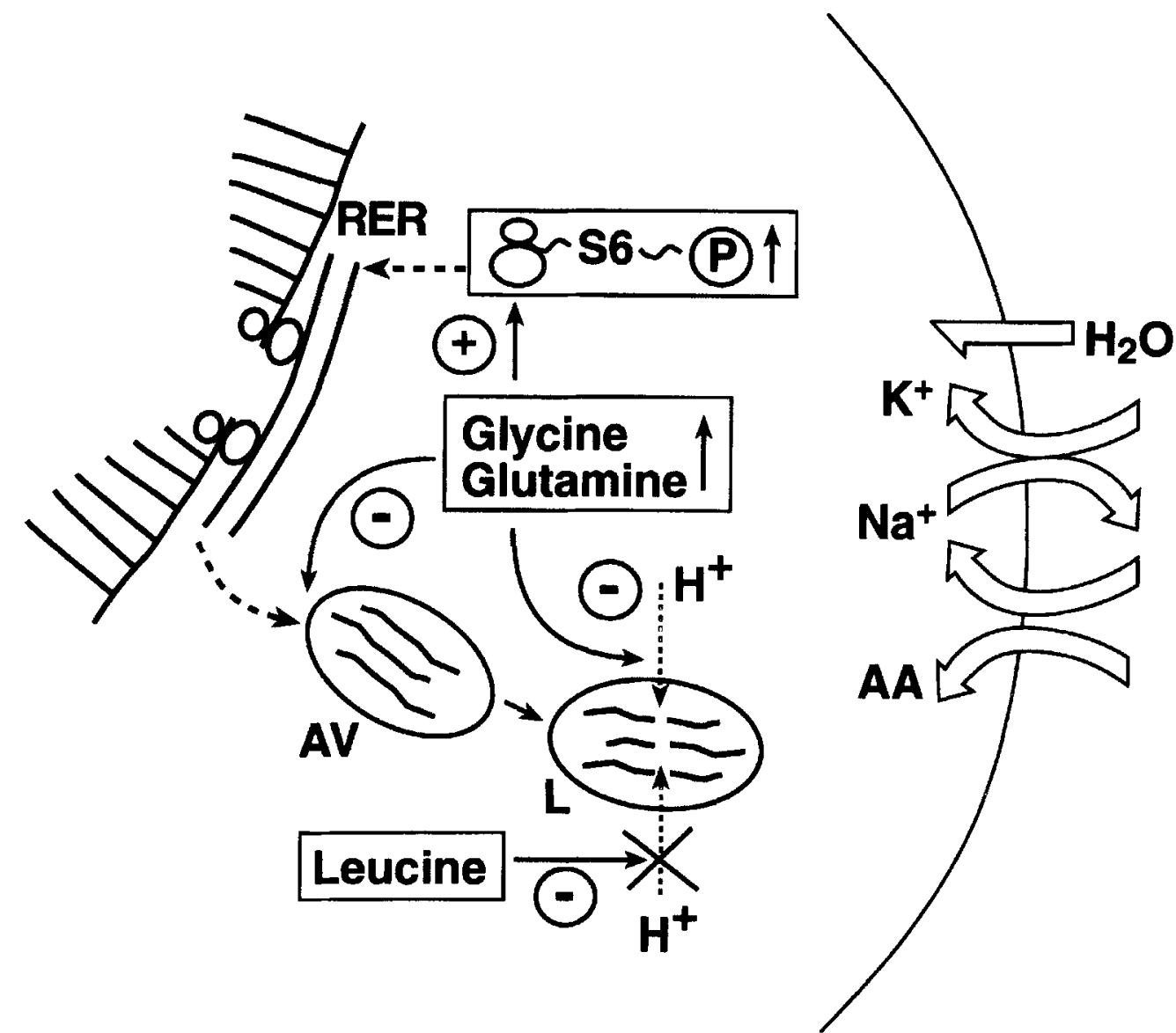

Fig. 3. Diagrammatic representation of putative mechanisms by which increases in cellular hydration, induced by transport of amino acids (AA) via the $\mathrm{Na}^{+}$-dependent $\mathrm{A}$ system, may result in both increased synthesis of export (plasma) protein and decreased constitutive protein degradation in liver. RER, rough endoplasmic reticulum; AV, autophagic vacuole; $\mathrm{L}$, lysosome; $\mathrm{H}^{+}$, proton pump of autophagic vacuole and lysosome; $\mathrm{S} 6 \sim \mathrm{P}$, phosphorylation of ribosomal protein S6 resulting in more ribosome attachment to RER. $\rightarrow$, Intracellular translocations; $\rightarrow$, control points. (Based on concepts of Häussinger et al. 1994; Luiken et al. 1994.)

\section{SUPPLY TO PERIPHERAL TISSUES}

The end result of liver metabolism is to allow entry of AA into the systemic blood supply to provide substrate for peripheral tissue protein gain. Conceptually, AA utilization would be most efficient when absorption from the animal matches exact needs (the non-ruminant concept of an 'ideal' protein source). In practice, for ruminants offered forages the absorbed AA follow the pattern in rumen microbial protein (Lobley et al. 1996), which is not well matched to peripheral tissue requirements (MacRae \& Reeds, 1980). The situation is further complicated by the differential extractions which occur across the liver and, even when allowance is made for specialized hepatic functions (e.g. methionine to cysteine or as methyl group supplier, phenylalanine to tyrosine and various neurotransmitters, glycine for removal of xenobiotics etc.), the relative excesses (or deficiencies) are magnified. For example, in relation to net absorption from the GIT two of the primary glucogenic AA, alanine and glycine, are almost completely extracted, which contrasts with the low 


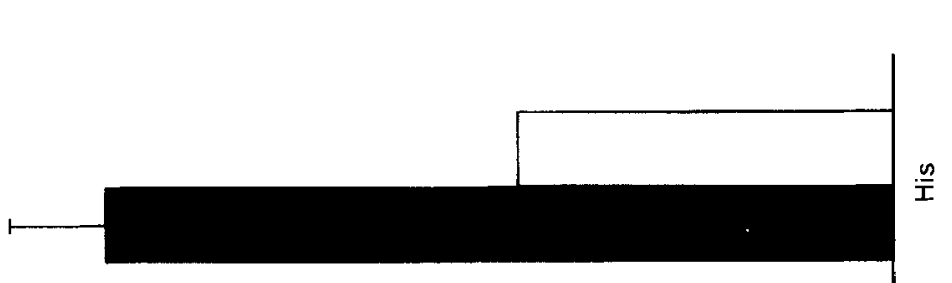

政

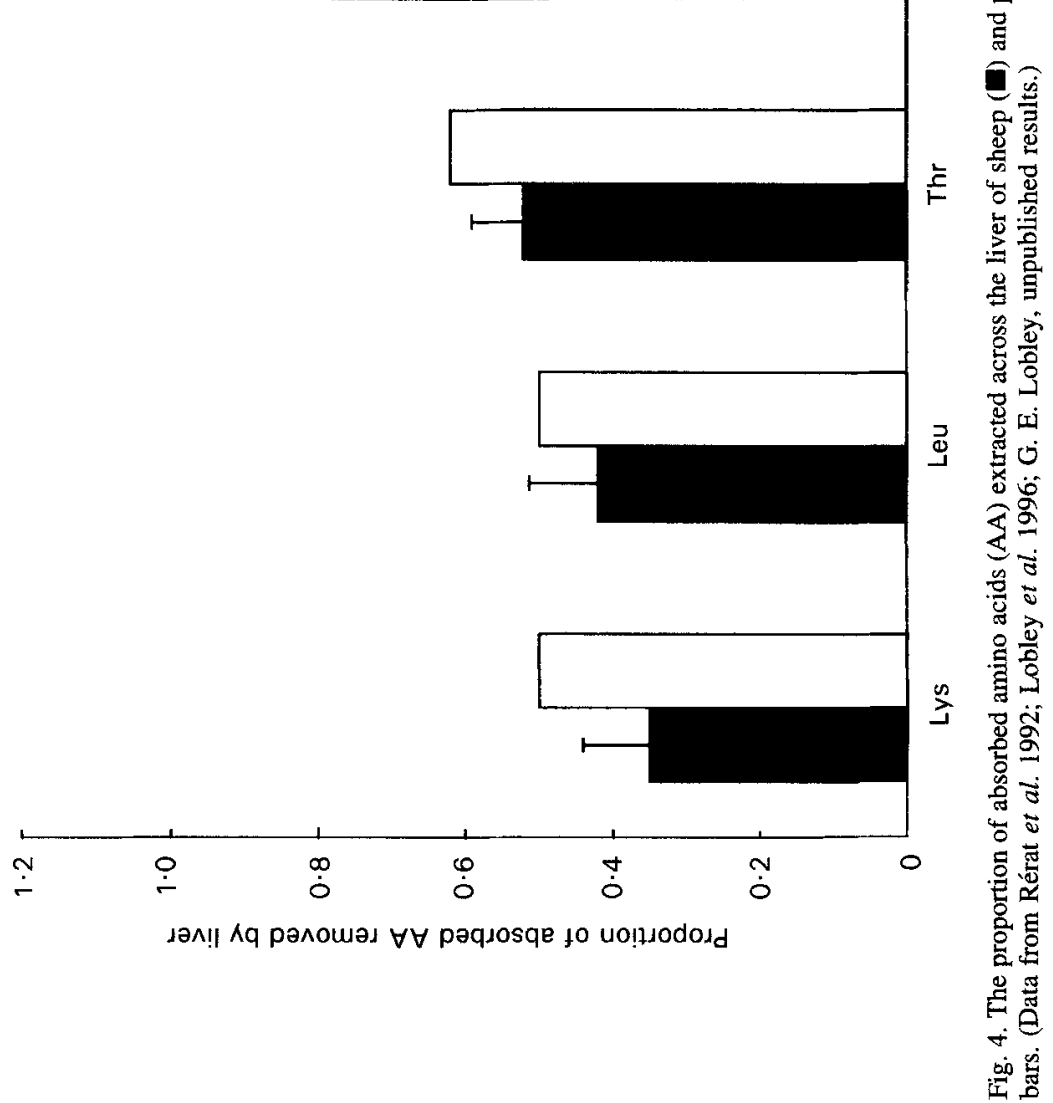


fractional extractions of the branched-chain AA (Fig. 4; see Lobley et al. 1995), despite considerable maximal potential in vitro (McGivan, 1992). The low removal in vivo may provide a mechanism to signal nutrient status to peripheral tissues and modulate their biosynthetic activity (Lobley, 1992). Thus, in rodents, man and commercial species, muscle sensitivity to insulin and IGF-1 is directly influenced by AA supply, most notably leucine (see Lobley, 1992; Crompton \& Dawson, 1997). These represent true examples of nutrient-hormone interactions.

In contrast, phenylalanine, which shares the same transporters ( $\mathrm{L}$ and ASC system; Christensen, 1990) as the branched-chain AA has a fractional extraction closer to unity, a feature shared with histidine (Fig. 4). The high removals for these two AA, and also methionine, raise two important questions: what is their fate in the liver and how is sufficient AA made available for peripheral tissue gain? In answer to the first question it has already been discussed that perhaps $77 \%$ and $90 \%$ of extracted phenylalanine and methionine respectively are destined for catabolic fates (Table 4). Why such extensive oxidation occurs is unclear, although methionine plays a key role in vital transmethylation reactions.

Approximately $50 \%$ of extracted histidine may be returned to the periphery within export proteins. This may provide a clue to the second question in that, compared with the composition of muscle protein, both albumin and serum globulins are relatively rich in both histidine and phenylalanine. Thus, if the relative proportions of AA in muscle protein are compared with net free AA supply beyond the liver, with phenylalanine considered as the reference base, then lean tissue gain would be restricted by histidine supply, with all other essential AA, including methionine, in excess (Fig. 5). If, however, the AA contained within the synthesized export proteins are available to peripheral tissue then, on a similar basis, the pattern of AA supply to requirement becomes more balanced, now with methionine as that in limitation (Fig. 5), which fits practical observations based on rumen microbial protein supply (Storm \& Ørskov, 1984). Thus, a daily synthesis of export proteins of $20 \mathrm{~g}$ may in fact provide enough appropriate AA to support $45-65 \mathrm{~g}$ muscle gain. Such a concept requires, of course, that peripheral tissues have the appropriate proteolytic mechanisms to utilize the plasma proteins as sources of free AA.

\section{CHALLENGES}

Most research on the large commercial species is directed towards specific aspects of animal productivity and, thus, the integrative effects of the various regulatory and counterregulatory mechanisms are of most importance. Throughout the present review it has been assumed that the fundamental processes are similar in ruminants and non-ruminants but, while this is probable, the magnitude and importance of specific mechanisms may differ. Thus, there is a vital requirement to determine the extent to which extrapolations can be made from the laboratory species.

So what are the challenges? First we must understand what determines the partition between anabolic and catabolic fates; can appropriate nutritional treatments inhibit ureagenesis? What is the consequence of an AA supply better balanced for peripheral tissues needs? The evidence from both pig studies and ruminants given AA supplements suggests that this must improve overall efficiency; if so, then hepatic AA catabolism is not simply controlled at the level of hepatic portal vein concentration but rather there must be regulation related to peripheral (and other) tissue needs and utilization. What are the mechanisms which underlie such regulation; are nutrient-hormone interactions involved and, if so, in which combinations? Is the 'smoothing' effect which hepatic removal exerts 


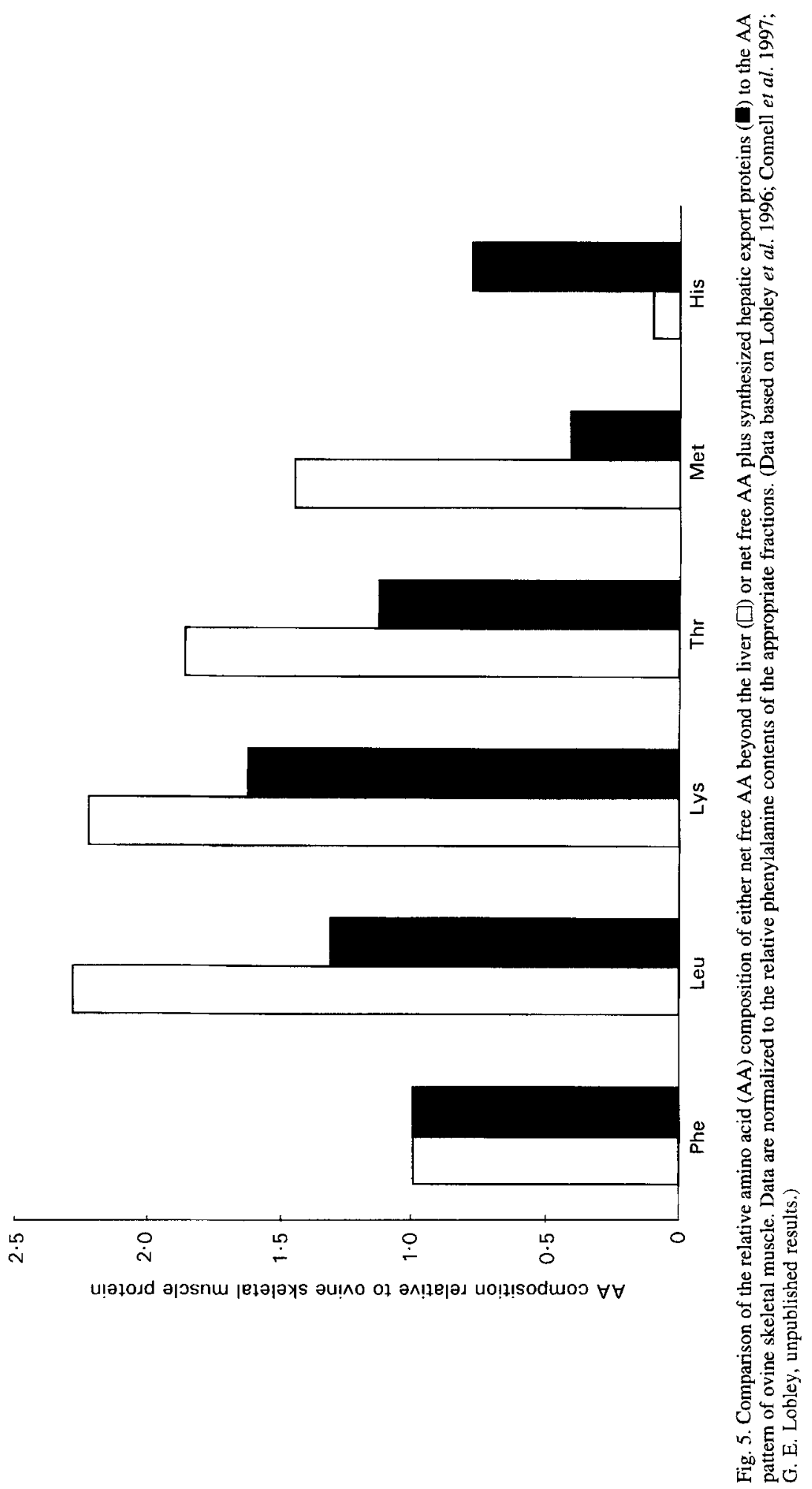


on peripheral AA concentration linked to synthesis of 'alternative' substrates, such as the plasma proteins; if so, are there limits to how much capacity and flexibility this allows to the animal? Do these controls remain in operation and unaltered during the lifetime of an animal or are they modulated with developmental status, physiological condition and ageing? Finally, how much variance in these mechanisms occurs between individuals and can this be used as a selection index to produce more advantageous genotypes?

\section{REFERENCES}

Abbott, E. M., Parkins, J. J. \& Holmes, P. H. (1985). Influence of dietary protein on the pathophysiology of ovine haemonchosis in Finn Dorset and Scottish Blackface lambs given a single moderate infection. Research in Veterinary Science 38, 54-60.

Attaix, D., Aurousseau, E., Bayle, G., Manghebati, A. \& Amal, M. (1987). Protein synthesis and degradation in growing lambs. In Protein Metabolism and Nutrition. European Association for Animal Production Publication no. 35, pp. 24-25 [J. Lehman, editor]. Rostock, Germany: Wilhelm-Pieck University.

Burrin, D. G., Ferrell, C. L., Britton, R. A. \& Bauer, M. (1990). Level of nutrition and visceral organ size and metabolic activity in sheep. British Joumal of Nutrition 64, 439-448.

Cathelineau, L., Petit, F. P., Coudé, F. X. \& Kamoun, P. P. (1979). Effect of propionate and pyruvate on citrulline synthesis and ATP content in rat liver mitochondria. Biochemical and Biophysical Research Communications 90, 327-332.

Christensen, H. N. (1990). Role of amino acid transport and countertransport in nutrition and metabolism. Physiological Reviews 70, 43-77.

Cohen, N. S. \& Kuda, A. (1996). Arginosuccinate synthetase and arginosuccinate lyase are localized around mitochondria: an immunocytochemical study. Journal of Cellular Biochemistry 60, 334-340.

Connell, A., Calder, A. G., Anderson, S. E. \& Lobley, G. E. (1997). Hepatic protein synthesis in the sheep: effect of intake as monitored by use of stable-isotope-labelled glycine, leucine and phenylalanine. British Journal of Nutrition 77, 255-271.

Crompton, L. A. \& Dawson, J. M. (1997). Nutritional control of muscle protein turnover in ruminants. Proceedings of the Nutrition Society 56, (In the Press).

Demigné, C., Yacoub, C., Morand, C. \& Rémésy, C. (1991). Interactions between propionate and amino acid metabolism in isolated sheep hepatocytes. British Journal of Nutrition 65, 301-317.

Garwacki, S., Wiechetek, M., Karlik, W., Souffrant, W.-B. \& Krawielitzki, K. (1990). Effect of propionate on the utilization of nitrogen from ${ }^{15} \mathrm{NH}_{4} \mathrm{Cl}$ for urea synthesis in hepatocytes isolated from sheep liver. International Journal of Biochemistry 22, 1185-1188.

Häussinger, D. (1990). Nitrogen metabolism in liver: structural and functional organization and physiological relevance. Biochemical Journal 267, 281-290.

Häussinger, D., Hallbrucker, C., Saha, N., Lang, F. \& Gerok, W. (1991). Cell volume is a major determinant of proteolysis control in liver. FEBS Letters $283,70-72$.

Häussinger, D., Lamers, W. H. \& Moorman, A. F. M. (1992a). Hepatocyte heterogeneity in the metabolism of amino acids and ammonia. Enzyme 46, 72-93.

Häussinger, D., Lang, F., Bauers, K. \& Gerok, W. (1990). Interactions between glutamine metabolism and cell volume regulation in perfused rat liver. European Journal of Biochemistry 188, 689-695.

Häussinger, D., Lang, F. \& Gerok, W. (1994). Regulation of cell function by the cellular hydration state. American Journal of Physiology 267, E343-E355.

Häussinger, D., Stoll, B., Morimoto, Y., Lang, F. \& Gerok, W. (1992b). Anisoosmotic liver perfusion: redox shifts and modulation of $\alpha$-ketoisocaproate and glycine metabolism. Biological Chemistry Hoppe-Seyler 373, $723-734$.

Hensgens, H. E. S. J., Verhoeven, A. J. \& Meijer, A. J. (1980). The relationship between intramitochondrial Nacetylglutamate and activity of carbamoyl-phosphate synthetase (ammonia). The effect of glucagon. European Journal of Biochemistry 107, 197-205.

Hesketh, J. (1994). Translation and the cytoskeleton: a mechanism for targeted protein synthesis. Molecular Biology Reports 19, 233-243.

Hunter, K. A., Ballmer, P. E., Anderson, S. E., Broom, J., Garlick, P. J. \& McNurlan, M. A. (1995). Acute stimulation of albumin synthesis rate with oral meal feeding in healthy subjects measured with [ring- ${ }^{2} \mathrm{H}_{5}$ ] phenylalanine. Clinical Science 88, 235-242.

Karasik, A., Rothenberg, P. L., Yamada, K., White, M. F. \& Kahn, C. R. (1990). Increased protein kinase C activity is linked to reduced receptor autophosphorylation in liver of starved rats. Journal of Biological Chemistry 265, 10226-10231.

Lobley, G. E. (1992). Control of the metabolic fate of amino acids in ruminants: a review. Journal of Animal Science 70, 3264-3275. 
Lobley, G. E., Connell, A., Lomax, M. A., Brown, D. S., Milne, E., Calder, A. G. \& Farningham, D. A. H. (1995). Hepatic detoxification of ammonia in the ovine liver: possible consequences for amino acid catabolism. British Journal of Nutrition 73, 667-685.

Lobley, G. E., Connell, A., Milne, E., Newman, A. M. \& Ewing, T. A. (1994). Protein synthesis in splanchnic tissues of sheep offered two levels of intake. British Journal of Nutrition 71, 3-12.

Lobley, G. E., Weijs, P. J. M., Connell, A., Calder, A. G., Brown, D. S. \& Milne, E. (1996). The fate of absorbed and exogenous ammonia as influenced by forage or forage-concentrate diets in growing sheep. British Journal of Nutrition 76, 231-248.

Luiken, J. J. F. P., Aerts, J. M. F. G. \& Meijer, A. J. (1996). The role of intralysosomal pH in the control of autophagic proteolytic flux in rat hepatocytes. European Journal of Biochemistry 235, 564-573.

Luiken, J. J. F. P., Blommaart, E. F. C., Boon, L., van Woerkom, G. M. \& Meijer, A. J. (1994). Cell swelling and the control of autophagic proteolysis in hepatocytes: involvement of phosphorylation of ribosomal protein $\mathbf{S 6}$ ? Biochemical Society Transactions 22, 508-511.

Luo, Q. J., Maltby, S. A., Lobley, G. E., Calder, A. G. \& Lomax, M. A. (1995). The effect of amino acids on the metabolic fate of ${ }^{15} \mathrm{NH}_{4} \mathrm{Cl}$ in isolated sheep hepatocytes. European Journal of Biochemistry 228, $912-917$.

McGivan, J. D. (1992). Techniques used in the study of plasma membrane amino acid transport. In Mammalian Amino Acid Transport. Mechanisms and Control, pp. 51-63 [M. S. Kilberg and D. Häussinger, editors]. New York: Plenum Press.

MacRae, J. C. \& Reeds, P. J. (1980). Prediction of protein deposition in ruminants. In Protein Deposition in Animals, pp. 225-249 [P. J. Buttery and D. B. Lindsay, editors]. London: Butterworths.

Meijer, A. J., Lamers, W. H. \& Chamuleau, R. A. F. M. (1990). Nitrogen metabolism and ornithine cycle function. Physiological Reviews 70, 701-748.

Meijer, A. J., Lof, C., Ramos, I. C. \& Verhoeven, A. J. (1985). Control of ureogenesis. European Journal of Biochemistry 148, 189-196.

Mortimore, G. E. \& Pösö, A. R. (1987). Intracellular protein catabolism and its control during nutrient deprivation and supply. Annual Review of Nutrition 7, 539-564.

Mutsvangwa, T., Buchanan-Smith, J. G. \& McBride, B. W. (1995). Interactions between ruminal degradable nitrogen intake and in vitro addition of substrates on patterns of amino acid metabolism in isolated ovine hepatocytes. Journal of Nutrition 126, 209-218.

Nieto, R., Calder, A. G., Anderson, S. E. \& Lobley, G. E. (1996). Method for the determination of ${ }^{15} \mathrm{NH}_{3}$ enrichment in biological samples by gas chromatography/electron impact ionization mass spectrometry. Journal of Mass Spectrometry 31, 289-294.

Orzechowski, A. \& Motyl, T. (1989). Metabolism of propionate and ammonia in isolated sheep liver mitochondria. Journal of Animal Physiology and Animal Nutrition 61, 9-18.

Orzechowski, A., Motyl, T., Pierznowski, G. \& Barej, W. (1987). Hepatic capacity for ammonia removal in sheep. Journal of Veterinary Medicine 34A, 108-112.

Orzechowski, A., Pierzynowski, S., Motyl, T. \& Barej, W. (1988). Net hepatic metabolism of ammonia, propionate and lactate in sheep in relation to gluconeogenesis and ureagenesis. Journal of Animal Physiology and Animal Nutrition 59, 113-122.

Owczarczyk, B. \& Barej, W. (1975). The different activities of arginase, arginine synthetase, ornithine transcarbamoylase and $\delta$-ornithine transaminase in the liver and blood cells of some farm animals. Comparative Biochemistry and Physiology 50B, 555-558.

Quillard, M., Husson, A. \& Lavoinne, A. (1996). Glutamine increases arginosuccinate synthetase mRNA levels in rat hepatocytes. The involvement of cell swelling. European Journal of Biochemistry 236, 56-59.

Rattenbury, J. M., Kenwright, A. M., Withers, C. J. \& Shepherd, D. A. L. (1983). Effect of propionic acid on urea synthesis by sheep liver. Research in Veterinary Science 35, 61-63.

Reaich, D., Channon, S. M., Scrimgeour, C. M. \& Goodship, T. H. J. (1992). Ammonium chloride-induced acidosis increases protein breakdown and amino acid oxidation in humans. American Journal of Physiology 263, E735-E739.

Rérat, A., Simoes-Nuñes, C., Mendy, F., Vaissaide, P. \& Vaugelade, P. (1992). Splanchnic fluxes of amino acids after duodenal infusion of carbohydrate solutions containing free amino acids or oligopeptides in the nonanaesthetized pig. British Journal of Nutrition 68, 111-138.

Reynolds, C. K. (1992). Metabolism of nitrogenous compounds by ruminant liver. Joumal of Nutrition 122 , 850-854.

Reynolds, C. K., Tyrrell, H. F. \& Reynolds, P. J. (1991). Effects of diet forage-to-concentrate ratio and intake on energy metabolism in growing beef heifers: whole body energy and nitrogen balance and visceral heat production. Journal of Nutrition 121, 994-1003.

Richardson, T. C., Jeacock, M. J. \& Shepherd, D. A. L. (1982). The effect of implantation of anabolic steroids into suckling and ruminating lambs on the metabolism of alanine in livers perfused in the presence or absence of volatile fatty acids. Journal of Agricultural Science, Cambridge 99, 391-401.

Schliess, F., Schreiber, R. \& Häussinger, D. (1995). Activation of extracellular signal-regulated kinases Erk-1 and Erk-2 by cell swelling in H4IIE hepatoma cells. Biochemical Journal 309, 13-17. 
Stewart, P. M. \& Walser, M. (1980). Failure of the normal ureagenic response to amino acids in the organic-acid loaded rat: a proposed mechanism for the hyperammonemia of propionic and methylmalonic acidemia. Journal of Clinical Investigation 66, 484-492.

Stoll, B., Gerok, W., Lang, F. \& Häussinger, D. (1992). Liver cell volume and protein synthesis. Biochemical Journal 287, 217-222.

Stoll, B., McNelly, S., Buscher, H. P. \& Häussinger, D. (1991). Functional hepatocyte heterogeneity in glutamate, aspartate and $\alpha$-ketoglutarate uptake: a histoautoradiographical study. Hepatology 13, $247-253$.

Storm, E. \& Ørskov, E. R. (1984). The nutritive value of rumen micro-organisms in ruminants. 4 . The limiting amino acids of microbial protein in growing sheep determined by a new approach. British Journal of Nutrition $52,613-620$.

Symonds, H., Denise, W., Mather, L. \& Collins, K. A. (1981). The maximum capacity of the bovine liver to metabolize ammonia. Proceedings of the Nutrition Society 40, 63A.

Verhoeven, A. J., Hensgens, E. S. J., Meijer, A. J. \& Tager, J. M. (1982). On the nature of the stimulation by glucagon of citrulline synthesis in rat-liver mitochondria. FEBS Letters 140, 270-272.

vom Dahl, S., Hallbrucker, C., Lang, F., Gerok, W. \& Häussinger, D. (1991). Regulation of cell volume in the perfused rat liver by hormones. Biochemical Journal 280, 105-109.

vom Dahl, S. \& Häussinger, D. (1996). Nutritional state and the swelling-induced inhibition of proteolysis in perfused rat liver. Journal of Nutrition 126, 395-402.

vom Dahl, S., Stoll, B., Gerok, W. \& Häussinger, D. (1995). Inhibition of proteolysis by cell swelling in the liver requires intact microtubular structures. Biochemical Journal 308, 529-536.

Wilton, J. C., Gill, M. \& Lomax, M. A. (1988). Uptake of ammonia across the liver of forage-fed cattle. Proceedings of the Nutrition Society 47, 153A.

Wolff, J. E. \& Bergman, E. N. (1972). Gluconeogenesis from plasma amino acids in fed sheep. American Journal of Physiology 223, 455-460. 